\title{
Cardiomyopathy and Pregnancy
}

\author{
A. K. BROWN, N. DOUKAS, W. D. RIDING, AND E. WYN JONES
}

From Liverpool Regional Cardiac Centre, Sefton General Hospital, Liverpool, 15

There is considerable doubt whether or not a syndrome of "post-partum cardiomyopathy" exists as a distinct clinical entity. Meadows (1960) has made an extensive review of previously reported cases and suggests that a characteristic clinicopathological condition bearing a causal relation to pregnancy can be delineated. The clinical features consist of dyspncea, præcordial pain, congestive cardiac failure, triple rhythm, tachycardia, emboli, and transient hypertension, and symptoms may start in the last trimester or in the puerperium.

Few cases corresponding to the Meadows' syndrome have been reported from Great Britain and in reported series of patients suffering from cardiomyopathy only 3 out of 50 (Brigden, 1.957) and 1 out of 60 (Goodwin et al., 1961) can be classified under the heading of post-partum cardiomyopathy. A further case has been described under the title of puerperal cardiomyopathy (Rosen, 1959).

We report 3 patients diagnosed as suffering from post-partum cardiomyopathy. One of them has been found to have previous electrocardiographic evidence of obscure myocardial disease, and the xtiology in the other two is discussed with particular reference to the preceding pregnancy. In addition, we have reviewed the obstetric histories of our patients diagnosed as having idiopathic cardiomyopathy to see the influence of pregnancy on the heart disease and to compare the clinical features with those of so-called post-partum cardiomyopathy.

\section{Case Reports}

Case 1. This woman, aged 33 years, was first seen in March 1965 when seven and a half months pregnant. She gave a three-week history of orthopnœa and increasing dyspnoea on exertion.

On examination, the jugular venous pressure was 6 $\mathrm{cm}$. above the sternal angle with a tall ' $a$ ' wave, and the liver was enlarged to $3 \mathrm{~cm}$. below the costal margin. Fine crepitations were present at both lung bases but

Received May 6, 1966. there was no peripheral œdema. The pulse was regular-110 a minute and of small volume, and the blood pressure was $100 / 55 \mathrm{~mm}$. $\mathrm{Hg}$. The apex beat was in the 5 th interspace 4 in. $(10 \mathrm{~cm}$.) from the midline, and there was a palpable gallop rhythm. Auscultation revealed a summation gallop with a soft mid-systolic murmur at the lower sternal edge and a moderately loud apical pansystolic murmur.

Investigations. The electrocardiogram showed $Q$ waves in leads III and AVF, with $T$ wave inversion in leads I, II, AVL, and V5-6. Chest $x$-ray film showed a normal cardiac contour but a cardiothoracic ratio of 60 per cent. Hæmoglobin $10.1 \mathrm{~g} . / 100 \mathrm{ml}$., with normal white cell count. Serum proteins $6.2 \mathrm{~g} . / 100 \mathrm{ml}$., with normal electrophoresis. L.E. test negative. Gum biopsy normal. Toxoplasma and viral serology negative. Serum electrolytes normal. Serum cholesterol $242 \mathrm{mg} . / 100 \mathrm{ml}$. Wassermann reaction negative.

Previous History. In four previous pregnancies, she had two full-term deliveries and two abortions at 10 weeks and 13 weeks, respectively. The last pregnancy was in 1958. She denied any previous heart abnormality, but subsequently remembered an episode of transient hemiparesis in 1959. An electrocardiogram taken at that time showed similar abnormalities to those noted on the record taken in March 1965.

Progress and Management. She was treated with bedrest, digoxin, and daily frusemide, and the dyspnœa improved. Spontaneous labour occurred on May 19, but the fœtal heart stopped without warning during the second stage and a stillborn infant was delivered. Treatment was continued in the puerperium and tubal ligation was performed five days post partum.

Cardiac catheterization was performed on August 23, 1965. The following pressures were recorded. Pulmonary artery $63 / 28 \mathrm{~mm}$. $\mathrm{Hg}$ (mean 43). Right ventricular pressure $62 / 5 \mathrm{~mm}$. $\mathrm{Hg}$. Right atrial mean pressure $2.5 \mathrm{~mm}$. Hg. Aorta $100 / 60 \mathrm{~mm}$. Hg. Left ventricle $100 \mathrm{~mm}$. $\mathrm{Hg}$ (systolic). Left ventricular enddiastolic pressure $20 \mathrm{~mm}$. $\mathrm{Hg}$. Left atrial mean pressure $22 \mathrm{~mm}$. $\mathrm{Hg}$. There was no diastolic gradient over the mitral or tricuspid valves, and outflow tract gradients 
could not be induced by Valsalva manœuvres or by amyl nitrite inhalations. Retrograde left ventricular cine-angiography showed a large dilated left ventricle and a minor degree of mitral regurgitation.

When seen in January 1966 she was still orthopnœic with occasional bouts of paroxysmal nocturnal dyspncea and was taking regular oral diuretics.

Case 2. This woman was 25 years of age. Dyspnœa, palpitations, cough with a little mucoid sputum, and a non-irritant, red papular rash started during the last month of her fifth pregnancy. On December 29, 1964 she had a full-term normal delivery at home. During January 1965 dyspnoea increased and she was seen in the Medical Unit at Whiston Hospital on February 7, 1965. She was dyspnoic at rest; a few pink spots 0.5 $\mathrm{cm}$. in diameter were present on both thighs and calves; the pulse was regular and fast $(140 / \mathrm{min}$.) and the blood pressure was $105 / 90 \mathrm{~mm}$. Hg. Her apex beat was 4.5 in. from the midline, and auscultation revealed a summation gallop and a soft apical systolic murmur conducted to the axilla. Jugular venous pressure was raised and there was tender hepatomegaly. A few inspiratory and expiratory rhonchi were detected in the chest.

Investigations. Electrocardiogram showed a left bundle-branch block. Chest $x$-ray film showed considerable increase in the size of the cardiac shadow. Hæmoglobin $13 \mathrm{~g} . / 100 \mathrm{ml}$. ESR $5 \mathrm{~mm}$. in one hour. WBC $8600 /$ c.mm. Serum proteins showed a slight increase in $\alpha_{2-}$ and $\beta$-globulins. L.E. test negative. Cold agglutins were absent. Serum for viral studies showed no significant titres. Serum electrolytes were normal. Dye test for toxoplasma was positive at a titre of $1 / 64$. Skin biopsy from a lesion on the left thigh showed hyperkeratosis, with occasional plugging of hair follicles. There was no evidence of lupus erythematosus, and the changes were regarded as non-specific. Previous chest $x$-ray films in 1957 and 1961 were within normal limits.

Subsequent Progress and Management. She was treated with bed-rest, digoxin, and daily frusemide. The temperature remained normal throughout her stay in hospital. Three weeks after the start of treatment there was no gallop rhythm and the jugular venous pressure was normal. On March 10, sterilization by tubal ligation was performed.

When seen in August 1965, the patient was asymptomatic and there were no abnormal physical signs. Chest $x$-ray film showed a normal heart contour and cardiothoracic ratio, but the electrocardiogram still showed a left bundle-branch block.

Case 3. This patient was aged 33. Cough, paroxysmal nocturnal dyspncea, and peripheral odema developed in the second and third weeks after her fourth pregnancy in April 1962. During the pregnancy her blood pressure had risen to $140 / 90 \mathrm{~mm}$. $\mathrm{Hg}$ with slight albuminuria, but a chest $x$-ray film taken three months ante partum was within normal limits.

On examination, she was in sinus rhythm with a blood pressure of $150 / 110 \mathrm{~mm} . \mathrm{Hg}$. The apex beat was in the anterior axillary line; there was a triple rhythm, a faint pansystolic murmur, jugular venous engorgement, peripheral œdema, and hepatomegaly. The spleen was just palpable.

Investigations. Hæmoglobin 13.2 g. $/ 100 \mathrm{ml}$., white cell count normal. Total serum proteins $6.4 \mathrm{~g} . / 100 \mathrm{ml}$., with normal electrophoresis. The Mantoux test was positive at 1 in 10,000; blood cultures were negative; L.E. cells were not demonstrated. Proteinuria was noted on many occasions. Chest $x$-ray film confirmed the cardiac enlargement and the electrocardiogram showed a left bundle-branch block.

Subsequent Progress. She was treated with bed-rest, thiazides, and spironolactone. Her blood pressure varied from $160 / 100$ to $130 / 90 \mathrm{~mm}$. Hg over the next 12 months, and her symptoms steadily improved. Serial chest $x$-ray films showed a steady diminution in the size of the heart shadow and the electrocardiogram became normal 18 months after the date of delivery.

In January 1963 her hæmoglobin was $7 \mathrm{~g} . / 100 \mathrm{ml}$. and her exercise tolerance had deteriorated. The spleen could just be felt below the costal margin. Extensive investigation failed to reveal the cause of the anæmia; in particular there was no evidence of occult bleeding and barium studies failed to show esophageal varices or peptic ulceration. Treatment with oral and parenteral iron resulted in rapid clinical improvement.

In February 1965 she was readmitted to hospital in the 28th week of her fifth pregnancy with supraventricular tachycardia and a left bundle-branch block. Treatment with digitalis restored sinus rhythm with normal ventricular complexes, and she was kept in hospital to term. In the last six weeks of pregnancy her blood pressure was persistently raised to about $160 / 100 \mathrm{~mm}$. $\mathrm{Hg}$ and there was albuminuria. She was treated with bed-rest and sedation. Two days before the full-term delivery of normal twins, a routine electrocardiogram again showed a left bundle-branch block.

In addition to the tests which were done in the previous pregnancy, other investigations were performed. These included normal toxoplasma serology, viral complement-fixation tests, with a positive titre at 1 in 340 for measles (suggesting recent contact with measles virus), normal gum biopsy, negative Wassermann reaction, normal 24-hour excretion of urinary 17-oxosteroids, 17-oxogenic steroids, and catecholamines, and a test for antinuclear factor was negative.

Diuretics were given to suppress lactation, and there was no nocturnal dyspnœa or evidence of fluid retention in the puerperium. Hepatosplenomegaly was noted throughout pregnancy and persisted in the puerperium. Four days post partum she developed pyrexia and sore throat, and a blood film showed agranulocytosis. She was treated with ampicillin and the symptoms rapidly improved. The white cell count became normal over the following two weeks. Full hæmatological investigations were performed and the direct Coombs' test was found to be positive, though no other evidence of hæmolysis was demonstrated. Sternal marrow examination 
TABLE I

SUMMARY OF DIAGNOSES, OBSTETRIC HISTORIES, AND CLINICAL CONDITION OF PATIENTS STUDIED

\begin{tabular}{|c|c|c|c|c|}
\hline Case No. & Diagnosis & $\begin{array}{l}\text { No. of } \\
\text { pregnancies }\end{array}$ & $\begin{array}{l}\text { Symptoms during pregnancy } \\
\text { and/or puerperium }\end{array}$ & Present condition \\
\hline 1 & $\begin{array}{l}\text { Obscure myocardial } \\
\text { disease }\end{array}$ & 5 & $\begin{array}{l}\text { Dyspncea and left ventricular failure in last } \\
\text { trimester of } 5 \text { th pregnancy }\end{array}$ & $\begin{array}{l}\text { Orthopncea and occasional paroxysmal noc- } \\
\text { turnal dyspncea; on digoxin and diuretics } \\
9 \mathrm{mth} \text {. post partum }\end{array}$ \\
\hline 2 & $\begin{array}{l}\text { "Meadows } \\
\text { syndrome" }\end{array}$ & 5 & $\begin{array}{l}\text { Dyspncea and palpitations in last mth. of } \\
\text { 5th pregnancy; severe congestive cardiac }\end{array}$ & Complete recovery by $8 \mathrm{mth}$. post partum \\
\hline 3 & $\begin{array}{l}\text { ? "Meadows, } \\
\text { syndrome" }\end{array}$ & 5 & $\begin{array}{l}\text { In 4th pregnancy developed cough for } 3 \mathrm{dy} \text {. } \\
\text { before delivery; paroxysmal nocturnal } \\
\text { dyspncea and congestive cardiac failure } \\
\text { post partum }\end{array}$ & $\begin{array}{l}\text { Supraventricular tachycardia and LBBB in } \\
5 \text { th pregnancy; anæmia and spleno- } \\
\text { megaly suggest underlying systemic dis- } \\
\text { order }\end{array}$ \\
\hline 4 & $\begin{array}{l}\text { Obstructive } \\
\text { cardiomyopathy }\end{array}$ & 1 & $\begin{array}{l}\text { Left ventricular failure in last } \mathrm{mth} \text {. of } \\
\text { pregnancy }\end{array}$ & Normal exercise tolerance \\
\hline 5 & $\begin{array}{l}\text { Obstructive } \\
\text { cardiomyopathy }\end{array}$ & 2 & & $\begin{array}{l}\text { Constant dyspnœea on exertion of moderate } \\
\text { severity }\end{array}$ \\
\hline 6 & $\begin{array}{l}\text { Obstructive } \\
\text { cardiomyopathy }\end{array}$ & 1 & Nil & $\begin{array}{l}\text { Fatigue and left ventricular failure for } 1 \mathrm{yr} \text {. } \\
\text { since onset of atrial fibrillation }\end{array}$ \\
\hline 7 & $\begin{array}{l}\text { Obstructive } \\
\text { cardiomyopathy }\end{array}$ & 6 & Palpitations in last $6 \mathrm{wk}$. of 6 th pregnancy & $\begin{array}{l}\text { Recurrent paroxysmal nocturnal dyspncea } \\
\text { and congestive cardiac failure }\end{array}$ \\
\hline 8 & $\begin{array}{l}\text { Familial } \\
\text { cardiomyopathy }\end{array}$ & 5 & Nil & Died aged 47 \\
\hline 9 & $\begin{array}{l}\text { Familial } \\
\text { cardiomyopathy }\end{array}$ & 2 & Nil & $\begin{array}{l}\text { No symptoms; diagnosis made on routine } \\
\text { examination }\end{array}$ \\
\hline 10 & Familial & 4 & Nil & Died aged 47 \\
\hline 11 & $\begin{array}{l}\text { Familial } \\
\text { cardiomyopathy }\end{array}$ & 1 & Nil & $\begin{array}{l}\text { No symptoms; diagnosis made on routine } \\
\text { examination }\end{array}$ \\
\hline 12 & $\begin{array}{l}\text { Familial } \\
\text { cardiomyopathy }\end{array}$ & 3 & Nil & $\begin{array}{l}\text { examination } \\
\text { Died aged } 53\end{array}$ \\
\hline 13 & $\begin{array}{l}\text { Familial } \\
\text { cardiomyopathy }\end{array}$ & 1 & Nil & $\begin{array}{l}\text { No symptoms; heart lesion diagnosed in } \\
\text { childhood }\end{array}$ \\
\hline 14 & $\begin{array}{l}\text { Obscure myocardial } \\
\text { disease }\end{array}$ & 2 & $\begin{array}{l}\text { Atrial flutter developed in last two mth. of } \\
\text { 4th pregnancy; sinus rhythm restored }\end{array}$ & No symptoms; third sound still audible \\
\hline 15 & $\begin{array}{l}\text { Obscure myocardial } \\
\text { disease }\end{array}$ & 2 & Nil & $\begin{array}{l}\text { Moderately disabled by exertional dyspncea } \\
\text { and chest discomfort }\end{array}$ \\
\hline
\end{tabular}

was normal and no evidence of reticulosis or collagen disease was found.

The patient was seen in June 1965. The spleen and liver were both enlarged to two finger breadths below the costal margin. Hæmoglobin $11 \cdot 1 \mathrm{~g} . / 100 \mathrm{ml}$., white cell count normal; electrocardiogram and chest $x$-ray film were normal. She has refused further investigations and has not attended the out-patient clinic since.

\section{Obstetric Histories of Patients with CARDIOMYOPATHY}

We have elicited the obstetric histories of 12 patients with cardiomyopathies of different types, and we propose to consider these patients in separate groups. Brief clinical details of these patients are shown in Table I.

Group 1 are those patients with obstructive cardiomyopathy, the criteria for diagnosis being a compatible clinical picture associated with phonocardiographic evidence of a mid-late systolic murmur and an indirect carotid artery tracing demonstrating the sharp upstroke and characteristic contour found in this condition. Four patients have been investigated, three have had cardiac catheterization, and the relevant catheter data are shown in Table II.

Case 4. She was 34. A heart lesion was noted on routine examination before pregnancy, but there were no symptoms until the last month of her only pregnancy when she was 26 years of age. Persistent nocturnal cough, orthopnœa, and paroxysmal nocturnal dyspnca were treated with bed-rest, digitalis, and diuretics, and labour was uneventful. There was no exacerbation of the symptoms during the puerperium.

Case 5. This patient, aged 45, had two uncomplicated pregnancies 14 years and 7 years before a cardiac abnormality was detected.

Case 6. This patient had a routine examination at 18 years of age when a heart lesion was revealed, but symptoms did not start until ten years later. When aged 20 she was delivered of a male infant by cæsarean section, and tubal ligation was performed at the same time. There was no evidence of cardiac decompensation during the pregnancy or the puerperium.

Case 7. This patient was 45. Heart disease was diagnosed before her first pregnancy but symptoms started in her sixth and last pregnancy. Palpitations started in the last six weeks, but there were no signs of left ventricular failure. She developed atrial fibrillation subsequently and has become severely disabled by her cardiac condition.

Group 2 concerns familial non-obstructive cardiomyopathy.

Obstetric histories were available in 6 patients found to have obscure myocardial disease and belonging to one family; the family pedigree is shown in the Figure. The 
TABLE II

CATHETER DATA FROM PATIENTS WITH OBSTRUCTIVE CARDIOMYOPATHY

\begin{tabular}{|c|c|c|c|c|c|c|c|c|c|}
\hline $\begin{array}{l}\text { Case } \\
\text { No. }\end{array}$ & $\begin{array}{l}\text { Right atrial } \\
\text { pressure } \\
\text { and mean } \\
(\mathbf{m m} . \mathbf{H g})\end{array}$ & $\begin{array}{c}\text { Right } \\
\text { ventricular } \\
\text { pressure } \\
\text { with end- } \\
\text { diastolic } \\
\text { (mm. Hg) }\end{array}$ & $\begin{array}{c}\text { Mean } \\
\text { pulmonary } \\
\text { artery } \\
\text { pressure } \\
\text { (mm. Hg) }\end{array}$ & $\underset{\text { RV-PA }}{\text { Gradient }}$ & $\begin{array}{l}\text { Left atrial } \\
\text { pressure } \\
\text { and mean } \\
(\mathrm{mm} . \mathbf{H g})\end{array}$ & $\begin{array}{c}\text { Left } \\
\text { ventricular } \\
\text { pressure } \\
\text { with end- } \\
\text { diastolic } \\
\text { (mm. Hg) }\end{array}$ & $\begin{array}{c}\text { Aortic } \\
\text { pressure } \\
\left(\mathbf{m m} . \mathbf{H g}_{\mathbf{g}}\right)\end{array}$ & $\begin{array}{l}\text { Gradient } \\
\text { LV-aorta }\end{array}$ & $\begin{array}{l}\text { Left ventricular } \\
\text { angiography }\end{array}$ \\
\hline 4 & $\begin{array}{l}6 /-2 \\
(2)\end{array}$ & $110 / 0$ & $\begin{array}{c}45 / 30 \\
(35)\end{array}$ & 65 & - & $\begin{array}{l}230 / 25 \\
(25)\end{array}$ & $160 / 115$ & 70 & $\begin{array}{l}\text { Typical features } \\
\text { of obstructive }\end{array}$ \\
\hline 5 & $\begin{array}{c}10 / 5 \\
(8)\end{array}$ & $\begin{array}{c}45 / 8 \\
(8)\end{array}$ & $\begin{array}{c}45 / 25 \\
(30)\end{array}$ & 0 & $\begin{array}{c}27 / 15 \\
(18)\end{array}$ & $\begin{array}{c}125 / 15 \\
(15)\end{array}$ & $100 / 75$ & 15 & $\begin{array}{l}\text { Typical features } \\
\text { of obstructive }\end{array}$ \\
\hline 6 & $\begin{array}{l}12 / 6 \\
(10)\end{array}$ & $\begin{array}{c}42 / 8 \\
(8)\end{array}$ & $\begin{array}{c}40 / 20 \\
(33)\end{array}$ & 0 & $\begin{array}{c}30 / 15 \\
(21)\end{array}$ & $\begin{array}{c}100 / 15 \\
(15)\end{array}$ & $75 / 50$ & 25 & $\begin{array}{l}\text { Typical features } \\
\text { of obstructive } \\
\text { cardiomyopathy }\end{array}$ \\
\hline
\end{tabular}

propositus, a nulliparous woman aged 23, had full clinical investigation including right and left heart catheterization, and a non-obstructive cardiomyopathy was demonstrated.

Necropsy showed affection in three of the patients, and in the other three patients cardiomyopathy was diagnosed on the confirmed presence of an ejection systolic murmur and an atrial sound, electrocardiographic $x$-ray evidence of left ventricular hypertrophy, and an apex cardiogram showing a large ' $a$ ' wave, this giving indirect evidence of raised left ventricular end-diastolic pressure (Dimond and Benchimol, 1963).

Case 8. This patient, aged 47, had five uneventful pregnancies before discovery of her heart lesion at the age of 44 when she had palpitations due to atrial flutter. She died three years later and necropsy showed that death was due to a large pulmonary infarct, and there was ante-mortem thrombus in the right atrium. The heart was considerably enlarged with predominantly left ventricular involvement, but there was no evidence of valvular disease and the coronary arteries were patent.
Case 9. This patient, aged 27, was the daughter of Case 8. A diagnosis of familial cardiomyopathy was established in 1964 and she was followed through a normal pregnancy one year later. A previous pregnancy had been without incident.

Case 10. This patient was 47. Attention was drawn to the heart disease following a retinal embolus one year before her death. Necropsy showed a "nonspecific myocarditis". She had had four uneventful pregnancies.

Case 11. This patient, aged 33, had a normal pregnancy when she was 21 years, and familial cardiomyopathy was diagnosed two years later on routine examination as part of a study of the family.

Case 12. This patient was 53. The onset of atrial fibrillation seven years before her death was the first indication of cardiac disease. Post-mortem examination was reported as showing "non-specific myocardial disease", and particular mention was made of the normal coronary arterial tree and the absence of valvular

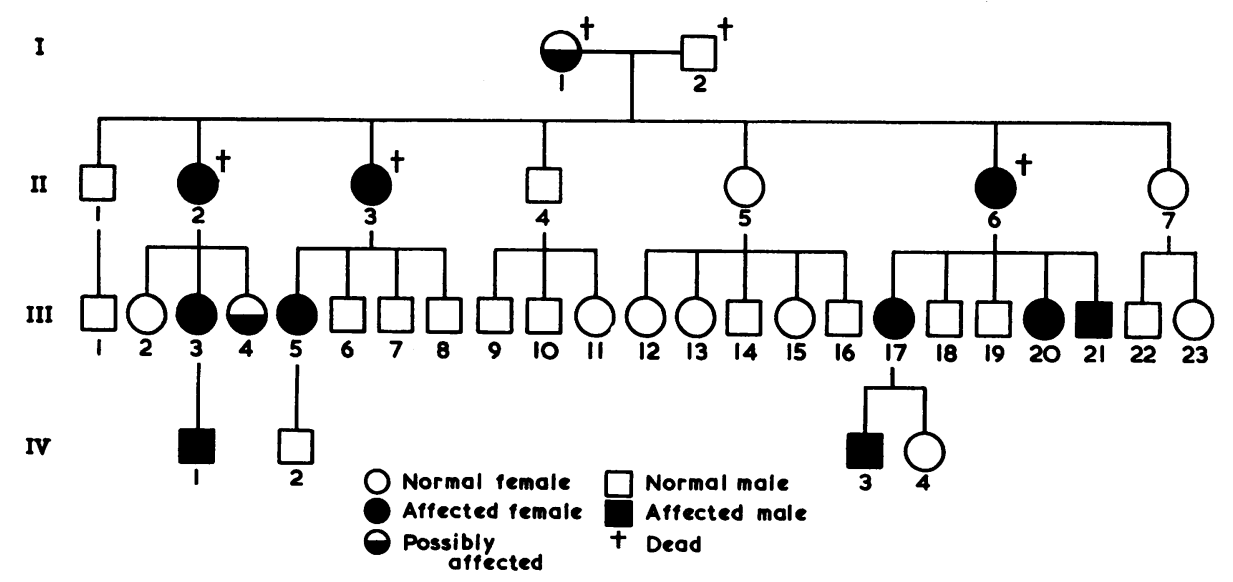

FIG. Family pedigree.-Familial non-obstructive cardiomyopathy. II.2, II.3, II.6, III.3, III.5, and III.17 are described in the text. 
disease. She had three normal pregnancies before the cardiac disorder was detected.

Case 13. This patient, the daughter of Case 12, was 34 and she was known to have had heart disease from childhood. She had one full-term normal delivery when she was 25 years.

Group 3 includes two patients, both with presumptive cardiomyopathy, non-obstructive, and with no family history.

Case 14. This patient, aged 28, presented with palpitations in the last two months of her second pregnancy. The electrocardiograph showed atrial flutter, and two weeks after delivery sinus rhythm was restored, by a single shock of 50 Joules, using DC countershock.

She is symptom-free at present, but chest $x$-ray film shows a slight increase in the cardiothoracic ratio, and there is a loud third sound on auscultation. Cardiac catheter studies have not yet been carried out.

Case 15. This patient, aged 32, had dyspnca on exertion which started when she was 28 , and she was noted to have a mid-systolic murmur in the aortic area. The electrocardiogram showed a left bundle-branch block. Cardiac catheterization in June 1964 failed to show evidence of obstructive cardiomyopathy, but the end-diastolic pressures at rest were $8 \mathrm{~mm}$. $\mathrm{Hg}$ in the right ventricle and $18 \mathrm{~mm} . \mathrm{Hg}$ in the left ventricle.

She had two normal full-term deliveries before the recognition of cardiac disease.

\section{Discussion}

Cardiomyopathy presenting during the last trimester of pregnancy or in the puerperium has been reported as a well-defined condition with a uniform clinical picture. Gouley, McMillan, and Bellet (1937) described seven cases with four deaths, and Hull and Hafkesbring (1937) reported 31 cases under the heading of "toxic postpartal heart disease". The clinico-pathological features have been summarized by Meadows (1957, 1960). Congestive cardiac failure is preceded by cough and paroxysmal nocturnal dyspnoea; præcordial pain may occur and embolic episodes are frequent. Examination shows a large heart with a triple rhythm, sinus tachycardia, transient hypertension, and electrocardiographic abnormalities, commonly $\mathrm{T}$ wave inversion. Symptoms may start in the last trimester and increase in severity post partum, but in most cases symptoms start in the puerperium. Multiparity, high maternal age, and twin pregnancies tend to show an increased incidence of the syndrome, and recurrence may be induced by subsequent pregnancies. Mortality has been reported as high as 60 per cent (Walsh et al., 1965), though an approximate figure for previously reported cases is
20 per cent. At necropsy, cardiac dilatation and ventricular mural thrombi have been stressed and microscopical examination characteristically shows myocardial degeneration, with fibrosis and minimal inflammatory cell reaction.

The alternative to acceptance of "Meadows' syndrome" as a disease in itself is to regard this clinical picture as a non-specific condition which may be caused by a variety of factors. Thus, underlying heart disease may be recognized when the physiological changes in late pregnancy and the puerperium cause cardiac embarrassment. Other factors such as poor nutrition, alcoholism, previous disease, and drugs may serve to predispose to cardiac failure when combined with the normal physiological stresses of pregnancy. Another explanation would be a specific form of cardiomyopathy presenting fortuitously in the last trimester of pregnancy or in the puerperium but without any ætiological connexion.

In the present series, the obstetric histories of 12 patients with idiopathic cardiomyopathy have been reviewed, and three of these patients have developed symptoms in the last trimester of pregnancy. One patient with obstructive cardiomyopathy (Case 4) developed orthopnoa four weeks before delivery. Her symptoms improved with bed-rest, digoxin, and diuretics, and there was no recurrence of symptoms in the puerperium. Two other patients have presented with arrhythmias in the last three months of pregnancy. One (Case 7) has clinical evidence of obstructive cardiomyopathy and is severely disabled by her heart disease. She presented first with palpitations in the last trimester of her sixth pregnancy and atrial fibrillation has become established subsequently. At present, 14 years after her sixth and last pregnancy, she is in congestive cardiac failure with angina pectoris and frequent syncopal bouts. The other patient (Case 14) developed dyspnoa and palpitations in the last two months of her second pregnancy. The electrocardiogram showed atrial flutter which was converted to sinus rhythm by DC countershock. She still has a loud third heart sound with slight cardiac enlargement on chest $x$-ray film, and it is hoped to investigate her more fully.

Gilchrist (1963) has attempted to classify pregnancy cardiomyopathies into two groups. One presents with congestive cardiac failure and the other is characterized by angina and tachycardia, congestive heart failure being rare. On the evidence of Case 7 it seems likely that some cases of obstructive cardiomyopathy may present as examples of Gilchrist's second group.

None of the familial cases in the present series has developed cardiac failure in pregnancy or the 
puerperium, but deterioration during and following pregnancy has been reported by other authors. Whitfield (1961) has reported that three of his cases of familial cardiomyopathy became worse in pregnancy and one of the patients described by Westlake, Cohen, and Willis (1962) developed palpitations in the second trimester. A patient described by Bishop, Campbell, and Wyn Jones (1962) developed severe cardiac failure two weeks after delivery. This patient had been found to have a pulmonary systolic murmur and a triple rhythm 10 years previously and was shown to have a familial cardiomyopathy.

Of the three patients in the present series who presented with congestive cardiac failure associated with pregnancy, Case 1 was shown to have preexisting cardiomyopathy and Case 3 had unexplained cardiomyopathy associated with hepatosplenomegaly, iron-deficiency anæmia, and a positive direct Coombs' test, which suggested that she had a systemic disorder with myocardial involvement, though it has not been possible to elucidate this further. Only one patient (Case 2) remains as a probable example of Meadows' syndrome. The apparent rarity of this type of case in this country may be due to failure of recognition, but it seems more likely that idiopathic post-partum cardiomyopathy is uncommon, or even non-existent, and it is necessary to investigate fully every patient who presents with obscure heart failure in pregnancy. Thus, a patient recently referred to the Cardiac Centre developed congestive cardiac failure in late pregnancy and has been shown since to have a tuberculous pericarditis, thereby emphasizing the need for caution in labelling cases as post-partum cardiomyopathy.

We have shown that patients with obscure cardiomyopathy may develop congestive cardiac failure or arrhythmias during pregnancy or the puerperium, and some of the examples of Meadows' syndrome, which have been reported previously, may be cases of idiopathic cardiomyopathy which happen to have presented during pregnancy or after delivery. It is unlikely that all cases of post-partum cardiomyopathy are caused by the discovery of previously unrecognized myocardial disease, and the apparent rarity of post-partum heart failure in Great Britain contrasts with the estimated incidence of 1 in every 1300 to 4000 births in the United States of America (Meadows, 1960). Most of the cases reported from the U.S.A. have occurred in Negroes, and it seems likely that environmental factors and possibly underlying infection are important. Of 15 cases reported by Meadows (1957), 6 gave a history of syphilis, but subsequent authors have not reported such a high incidence of venereal infection. Similarly, toxæmias of pregnancy and hypertensive heart disease have been stressed as ætiological factors (Benchimol, Carneiro, and Schlesinger, 1959), but other authors have been unimpressed with the relation. Inadequate nutrition has been mentioned in several reports and in a recent series 12 out of 15 patients were noted to have extremely deficient diets (Walsh et al., 1965). Seftel and Sussar (1961), in discussion of poor nutrition as a factor in the production of post-partum heart failure, have drawn attention to the similarity between a group of their African patients, with persistent cardiac enlargement, and a relatively common variety of obscure cardiomyopathy among Africans, which has been labelled nutritional heart disease. No convincing evidence of inadequate diet has been demonstrated in any of our patients and no history of excessive intake of alcohol has been elicited.

Pregnancy heart disease has been shown to be caused by a variety of specific agents, and suggested causes include sulphonamide hypersensitivity, influenzal myocarditis (Bashour and Winchell, 1954), Chagas' disease, miliary tuberculosis (Benchimol et al., 1959), and toxoplasmosis (Paulley et al., 1956). A dye test titre of $1 / 512$ or higher is regarded as presumptive evidence of toxoplasma infection (Fleck and Ludlam, 1965), and we accept the titre of 1/64 in Case 2 as a non-specific finding. Similarly, the positive measles complement-fixation test of $1 / 340$ in Case 3 is not considered important in the ætiology of the heart failure in a previous pregnancy.

Although no evidence of drug-induced cardiomyopathy has been found in the present cases, it is worth while considering a drug factor in patients presenting with heart failure associated with maternity. The pregnant woman is more likely to be receiving medications than the non-pregnant, and is, therefore, more liable to drug-induced disease. It may be noted that tetracycline has been implicated as one cause of acute fatty liver of pregnancy (Lancet, 1966), and it may be that drug-induced myocardial damage is responsible for a proportion of cases diagnosed as puerperal cardiomyopathy.

\section{SUMmaRY}

The obstetric histories of 15 patients with cardiomyopathy have been reviewed, and evidence from this series shows that patients with pre-existing cardiomyopathy may present with congestive cardiac failure or arrhythmias in the last trimester of pregnancy or in the puerperium. If the cardiomyopathy is not recognized before pregnancy, such patients may be regarded as examples of postpartum cardiomyopathy (Meadows' syndrome).

It is doubtful whether post-partum cardiomyo- 
pathy exists as a specific entity, and this diagnosis is considered likely in only one of the present cases. Environmental and social factors may be of ætiological importance in many of the cases reported by other authors, and full investigation may reveal the occasional patient who develops cardiomyopathy due to a known ætiological agent during pregnancy or the puerperium.

We are grateful to Dr. C. S. McKendrick, Dr. R. H. M. Ross, Dr. N. Coulshed, and Dr. E. J. Epstein for permission to report cases under their care.

\section{REFERENCES}

Bashour, F., and Winchell, P. (1954). "Post partal" heart disease-a syndrome? Ann. intern. Med., 40, 803.

Benchimol, A. B., Carneiro, R. D., and Schlesinger, P. (1959). Post-partum heart disease. Brit. Heart f., 21, 89.

Bishop, J. M., Campbell, M., and Wyn Jones, E. (1962). Cardiomyopathy in four members of a family. Brit. Heart F., 24, 715.

Brigden, W. (1957). Uncommon myocardial diseases. The non-coronary cardiomyopathies. Lancet, 2, 1243.

Dimond, E. G., and Benchimol, A. (1963). Correlation of intracardiac pressure and præcordial movement in ischæmic heart disease. Brit. Heart f., 25, 389.

Fleck, D. G., and Ludlam, G. B. (1965). Indications for laboratory tests for toxoplasmosis. Brit. med. F., 2, 1239.

Gilchrist, A. R. (1963). Cardiological problems in younger women: including those of pregnancy and the puerperium. Brit. med. f., 1, 209.

Goodwin, J. F., Gordon, H., Hollman, A., and Bishop, M. B. (1961). Clinical aspects of cardiomyopathy. Brit. med. F., 1, 69.

Gouley, B. A., McMillan, T. M., and Bellet, S. (1937). Idiopathic myocardial degeneration associated with pregnancy and especially the puerperium. Amer. F. med. Sci., 194, 185.

Hull, E., and Hafkesbring, E. (1937). "Toxic" postpartal heart disease. New Orleans med. surg. f., 89, 550.

Lancet (1966). Tetracyclines and the liver in pregnancy. $1,357$.

Meadows, W. R. (1957). Idiopathic myocardial failure in the last trimester of pregnancy and the puerperium. Circulation, 15, 903.

- (1960). Postpartum heart disease. Amer. F. Cardiol., 6, 788.

Paulley, J. W., Jones, R., Green, W. P. D., and Kane, E. P. (1956). Myocardial toxoplasmosis. Brit. Heart f., $18,55$.

Rosen, S. M. (1959). Puerperal cardiomyopathy. Brit. med. f., $2,5$.

Seftel, H., and Susser, M. (1961). Maternity and myocardial failure in African women. Brit. Heart f., 23, 43.

Walsh, J. J., Burch, G. E., Black, W. C., Ferrans, V. J., and Hibbs, R. G. (1965). Idiopathic myocardiopathy of the puerperium (postpartal heart disease). Circulation, 32, 19.

Westlake, R. E., Cohen, W., and Willis, W. H. (1962). Wolff-Parkinson-White syndrome and familial cardiomegaly. Amer. Heart f., 64, 314.

Whitfield, A. G. W. (1961). Familial cardiomyopathy. Quart. F. Med., 30, 119. 